\title{
TRES LECTURAS DE UN MITO TOBA
}

\author{
Maria Luisa ACUÑA \\ Norma PORTO de FARIAS \\ Orlando J. GENO
}

\section{INDICE}

"Mitos de origen de las mujeres"(transcripción)

Introducción

Capítulo I: Lectura simbólica del mito, por Maria Luisa Acuña

Capitulo Il: Lectura literaria del mito, por Norma Porto de Farias

Capitulo III: Lectura según la teoria de la enunciación, por Orlando J. Genó

Notas a los capitulos I, II y III.

Bibliografia de los capitulos I y III. 



\section{MITOS DE ORIGEN DE LAS MUJERES}

"Que esa gente que era de ese tiempo. Bueno, ese dia se empezaban a juntar esas gentes y no tenían mujeres; inada, todos esos eran varones! Y había, ¿qué voy a decir?, habia un campo lleno de agua y pescado; que esa era su vida, que en esa vida estaba esa gente. Pero sin mujeres, todos eran varones. Vivían los que viven en el monte, hombres, como les dicen acá; como a los que les dicen Matacos. En el monte estaban pero eran personas, como en forma de Nowet; todos salen de ése, de ése era esa gente".

"Que también habia un hombre, que tenia el poder ese hombre. Por eso tenía un compañero que volaba en el cielo, que miraba en todas partes; esa, Aguila era un espiritu, pero era persona también".

"Y hay un dia, que llegaron esas mujeres a robar la comida que tenia guardada esa gente. Lo llevaron todo, ni nada dejaron; que se les había antojado a esas mujeres ir a buscar y llevarse esa comida. ¡Ca!; y ellos pensaban: -Que, ¿qué quién se ha llevado nuestra comida?, que no puede ser que sean de acá, de la tierra. Entonces pensaron entre ellos: ¿¿Qué, a quién vamos a dejar acá?; ¿qué, que a un casero?, jeso, un caserol $Y$ ese es un hombre que, vamos a decir, es un loro, el Padre de los Loros; es en forma de hombre, pero él es el Padre de los Loros. Si vos tenés un loro, sale una persona si es que puede hablar ese loro, por eso él sale así. -Usted viejo -le dicen-, usted va a quedar acá con lo que tenemos guardando, jia ver qué gente es esa que se viene llevando estas cosas!' Y bueno, se quedó el Loro".

"Y los otros compañeros se fueron a buscar pescado"

"¡Bah, esa gente!, cuántas son esas gentes. Una gente que a veces parecen puros vacunos, entreverados todos. Habia personas, pero también estaban el Padre del Guasuncho, la Madre del Guasuncho, del Chacho; de todos esos bichos. ¿De dónde viene esa gente?; pero son todos hombres, Padre por Padre. Por el Padre salen también las iguanas, pero salen de él; que es persona; no se lo ve nunca, pero salen de él que es persona. $Y$ se junta esa gente; no sé si será Dios que los hace juntar, siendo de todas esas clases. Acá en el mundo hay muchos bichos; pero, voy a decir, ¿que de dónde salen todos esos bichos?: guasuncho, chancho, guanaco, carpincho, xuri; ¿que de adónde sale esta gente?: que es asi porque tienen a su Padre también, a su Padre que los cuida". 
"¿Y el Loro? Al rato, dicen, que el pobre viejo sintió un ruido. ¿¿Pero dónde, no sé de donde viene ese ruido? Y miraba el Loro. - ¿Será el sol, o la tierra, o un viento, lo que trae ese ruido?; y él miraba asi en la tierra y después miró en el cielo. Eran, no sé cuántas, las mujeres que venian en ese hilo, vamos a decir hilo pero es cadena; parecía un hilo y es largo ese hilo. Y las vio que venian del cielo".

"Venian del cielo. Al ratito, bajó una mujer y pide comida: -A ver viejito, a ver si nos convida que tenemos hambre. ¿Usted habia sido el casero?. -Si Señora, yo soy el casero -dice el Loro- . pero jarajo Señora!, yo no puedo darles la comida para que ustedes la alcen, hay que esperar a los otros. $Y$ miraba el pobre viejo. ¿ ¿Pero por qué nos mezquina usted Señor?, nos das o sino te matamos. Y claro, el Loro desconfió, y al rato se retiró; pero ya las otras alzaban cascotes para garrotearlo, y se voló; claro, tiene que disparar el pobrecito. Pero no hubo caso, entraron las mujeres a robarle; quiso volar y le largaron un cascote a la boca; ¡baj!, sonó el pobre. $Y$ estas mujeres dele alzar esa comida: pescado cocido, charqui de pescado. El Loro estaba asi, no podia hablar por un cascotazo que le garrotearon en la boca; lo quisieron matar pero asi nomás lo dejaron, y ya lo jodieron".

"Cuando llegaban los otros, ésas se apuraron y se fueron otra vez en esa cadena, en ese hilo; se fueron para el cielo. EI Loro miraba: - ¿Cómo no se cae esa cadena, cómo es que hacen esas mujeres? Es que una mujer sentada estaba pisando la cadena, ¿y cómo se iba a caer?, si estaba así, que te parece. Yo creo que el Dios manda esas mujeres, para que los otros las agarren y se queden también con ellas. Pero ellas no se presentaron como si vinieran a querer quedarse, sino que vienen a robar, en vez de decir que quieren quedarse acá, por si los otros las necesitan; jah, eso podían decir!, pero no, no lo dicen".

"Bueno, los otros vuelta otra vez a cazar los pescados; porque habia una bandada de pescados por alli; esa gente pescaba; entonces nosotros, los viejos, hemos seguido a esos pescadores de antes. Pero esos no eran personas, esos eran de otra clase de personas; esa pescada le tocó también a los indígenas, pero parece que esa gente venia a enseñarles lo que ellos no sabian todavia. Pèro, las mujeres vienen a llevarse esas cosas, toda la comida de esa gente".

"-Bueno -dicen- , vamos a elegir a cuál dejaremos mañana; mañana iremos a pescar otra vez, pero dejaremos a este hombre. Porque ése era un hombre bien compuesto, acomodado: ese hombre tiene un espiritu, el Aguila ésa; pero también es persona, también es persona digo; por eso puede hablar, es persona pero tiene alas; ese vuela, y cuando lo quieren joder se va; 
es hombre pero tiene alas. -Voy a esperar, voy a quedarme -dijo- . Porque él es el que maneja esa gente, es el comandante de la pescada; es el que cuida a toda esa gente ese hombre, el más sabedoso y poderoso. Ese vive en parte; sólo en parte es hombre; por eso ese hombre es muy poderoso. ¡Cuánta gente es la que tenia!".

"Bueno, se quedó y se fueron los otros. Le había dicho el pobre Loro: -Cuando usted sienta un ruido, bueno, entonces tenés que alistarte para que no te avancen esas mujeres. -Cuando yo pueda -dijo el Aguila- , entonces les pego un grito, a ver si me escuchan; cuando yo ya haya podido ver esas cosas, ver lo que hacen acá".

"Estaban los otros, al rato, dele cazar pescado. Al rato, sintió también un ruido el hombre. Un ruido que parecia un cañon, un ruido fuerte, ¡brum, brum! qque vienen, que ya venian, y lo oyó el hombre ésel; ya venían, y parecian un tiro así, mirá vos, todas formadas en fila. Por eso hacian un ruido, y hay tantos ruidos que vienen del cielo. Estaba asi, y tenia un machete el hombre ése; lo acomodó y afiló bien filoso. Así llegaron y ya pisaban en la tierra, arriba de la tierra las mujeres. Bajaron todas".

"Las mujeres tenían, vamos a decir, tenian una capataza; asi como las escuelas que tienen una maestra directora. Ella, que es la primerita, tiene que hablarle al hombre ese, al casero: -Bueno Don, ¿usted cuida acá?. Sí Señora, yo cuido acá la comida de mis compañeros. - ¿No se puede convidarnos a nosotras? -Pero mirá, hay que esperar a los compañeros, entonces todos las convidaremos a ustedes, a todas las convidaremos. Pero no, quieren disparar las mujeres, así nomás quieren hacer; siempre tienen que hacer asi y van a robarlo; pero el otro no quiso, el más corajudo habia sido este hombre, el Aguila. Entonces dijo la maestra, la directora: -Pero carajo, usted es mezquinoso; ¿por qué mezquina usted tanta comida cocida como hay acá, por qué no convida uno para cada una? -Pero no -dijo el Aguila- . Y no quiso convidar ni un pedazo. -Bueno, si usted mezquina las cosas para comer, entonces te mataremos, jte mataremos! -Y bueno, hágalo, si ustedes buscan eso, jháganlo, yo no disparo!".

"Cuando el Aguila se voló, las mujeres se levantaron en esa cadena, y así lo corrian con palos y cascotes. ¿Pero què, el hombre escapaba; juntaba las alas asi, y les escapaba a los golpes; cuando ve que le tiran, los ataja. Pero fijate vos, esa arma que le tiran al Aguila no es un pedazo de astilla o un pedazo de leña; ésa es otra arma, la que le tiraron al Aguila; por eso no se vive cuando ésa le pega a uno, ahi se muere nomás; esa arma es de ellas, pero no es revólver, ni escopeta, ni machete; ésa es otra 
clase de arma; por eso requiere un, hombre poderoso, vamos a decir, como un piogonak, ¿no?, cuando lo quiere joder a aquel que no tiene nada, y ya tiene que morirse ése. Esas son las cosas que tenian todas esas mujeres, armas poderosas. Por eso pueden decir cuando les mezquina el casero: - Mejor lo mataremos!: porque asi vienen armadas esas mujeres con todas las cosas que tienen".

"Se voló el Aguila, siempre va volando el hombre. Va cada vez más alto, cada vez más. Y las mujeres, cada vez más alto también, para seguirlo a ese hombre. Pero que, cuando llegó a la distancia justa para cortar la cadena esa, cuando llegó a la distancia de altura justa, entonces sacó el machete y cortó el hilo. Es cadena esa, pero voy a decir que es un hilo. 'Zas! y se: cayeron esas mujeres".

"Gritaba y gritaba el hombre para llamar a los otros: - Que vengan, que vengan! ¿Y quién va a sentir ese grito?, no lo sienten. $Y$ al rato una lguana que venia atrás; ¿quién via a creer que la iguana, que camina abajo, oyó un ruido?, el grito de ése: -Bueno -a los otros compañeros- , párense!, que he sentido el grito que gritaba ése. -Que va a ser -dijo uno- yo no he oído, yo que estoy parado más alto que vos quee va a oir el hornbre que está siempre abajol -Bueno -dijo la lguana-, perdoná compañero. Al rato paró esa gente y quedó quietita, Al ratito pegó otro grito el Aguila y entonces lo escucharon: -Ahí está -dicen- ya ha sido el grito. I ya se viene esa gente a todo lo que da, era como si fueran a correr una pelota; desnudos venian, no tenian nada porque estaban en el agua. $Y$ apurados cuando sienten el grito; jcon las ganas de alcanzar esas mujeresl, que a lo mejor están en el piso. $Y$ van. Hay hombres más ligeros y van a botar a los otros; son Iguana, Guasuncho, Xuri, Chuña, los más ligeros".

"Y en el camino se atravesó una, un pedazo de víbora asi, como si fuera alta asi; una vibora, jtremenda viboral, se atravesó. ¿Y qué van a hacer?, no pueden pasar los hombres y tienen que esperar. Un viejito, que le dicen Quirquincho porque siempre viene atrás, porque es un hombre chiquitito... ¿Y qué vamos a hacer?; la Chuña pega un salto y pasa al otro lado, viene el otro, salta, y pasa al otro lado; así todos los más ligeriss. Pero las demás personas no nueden saltar, de miedo a la vibora ésa, y dicen: - Esperemor! it ver si así no nos muerde más pronto; ¿y si esperamos al que tiene oubierta?. Ya sabés vos que el quirquincho tiene una cáscara, una cubierta corno un pan. Comenzó a revolcarse la víbora, y el hombrecito pasó por ahí; la vibora se levantó y picó, picó hasta que se rompió los dientes. Entonces ya pueden pasar los otros; porque es al Quirquincho al 
que la víbora alcanza pero le rompe todos los dientes. Ya pasó toda la gente, pero desnuda; los pescádos los dejaron en el agua de apurados, . porque el otro estaba gritando, dele llamarlos!".

'Entonces llegaron ahí. ¿De dónde vienen esas mujeres? El otro, el que las había hecho bajar, le dio dos mujeres al Xuri, al otro, otras dos, y así. ¿Qué me vas a creer vos que cuando bajaron esas mujeres, una entró en la tierra y está escondida ahí abajo?; ahị está, abajo de la tierra, abajo de un árbol".

"Bueno, ¿cómo podemos decir de Juan? Juan también hay, es de esa gente, Juan que le dicen, el Padre de los Zorros; ése también estuvo ahi junto con esa gente, jah!, pero era el Padre de los Zorros. Es como ya te dije, cualquier bicho tiene su Padre; no nacen como los gusanos que nacen de la tierra, esos gusanos nacen nomás de la tierra, pero los demás tienen su Padre; los demás, todos los que vemós acá en el Chaco, en el monte, todos esos tienen su Padre y tienen su Madre. Es por eso que el día que nacen, todos esos viven como nosotros arriba de esta tierra, arriba de este mundo".

"-Bueno, ¿cómo podemos hacer? -dice Juán- Juan con las ganas que tiene, ¿ah?; tanto es el tiempo en que no se ven las mujeres. Hay mujeres lindas, y éste quiere aprovechar jurito con algún otro. Los demás le decian: -No hermàno, ¿por qué no llamamos a la lguana, que tiene dos; a lo mejor estas mujeres tienen unos, unos dientes? ¿Sabés?, que habia sido que esas mujeres en la argolla tienen unos dientes. $Y$ los otros le mezquinaban a Juan para que no entrara; que mejor habia que llamar a la lguana que tiene dos pingos, y si perdía uno, le quedaba el otro. Pero el juán entra, él que nunca vio mujer. Ya va a ser, ya va a ser; va lo más tranquilo el Juan. El hombre ése, el Aguila, quería acomodarlas y mirarlas a esas mujêres; para ver si es que terían una cosa, como unos dientes; y se afligió por Juan. Por eso no hay que cogerlas tan pronto, porque él desconfiaba. Es que habian sido tan distintas esas mujeres, boca y boca; y no comen con esa de abajo, pero corta cuando la quieren coger".

"Juan dijo: - Yo voy a hacer un rato adentro, tengo que hacer adentro. $Y$ de repente gritó el Juan: ¡Qué carajo, que me cortaron el pingol $Y$ habia sido cierto, largaba sangre el pobre. Bueno, ése salió y le dice otro: - ¿Por qué no buscás un pedacito de hueso por ahí, a ver si se te compone? Juan se fue caminando por el monte y encontró un hueso de guasuncho: - ¿Cómo se hace con esto? -Acomódeselo así, bien ácomodado -le dicen los otrosque se habían estudiado bien el asunto entre ellos. ¿Sabés que el zorro, el de él es duro?; es duro porque es asi, un hueso que le hicieron colocar por ese que perdió". 
"Dijo entonces el hombre ése, el Aguila, el poderoso: -Ya tenemos mujer, hay piedras y van a hacer todo esto. $Y$ agarró una piedra, y las mujeres con ganas de hacer, abrieron las piernas; y cuando las abrieron, les pegaron un garrotazo con la piedra y les rompieron todo; y asi a la otra, y a la otra y a la otra, hasta que saltaron los dientes y ya no tenian nada; les rompieron todo eso".

"Y después las tantearon otra vez. Entonces llamaron otra vez a la Iguana. Después de ir, dijo la Iguana: -Está bien, ya pasó, ya pasó eso; ya no hay peligro, ya no hacen nada. iContenta la gente!, contenta porque ya les rompieron todo eso. Hasta ahi eșa gente vivia sin mujeres; pero al otro dia viene otro y otro, y se encuentran: -Bueno -dicen- , ahora estamos bien, ahora tenemos Señora. Entonces crece esa gente cada vez más, y se van para otras partes; dos para acá, dos para allá, se desparraman para hacer cria por todos lados. Se van para todos lados y a cada parte se van dos".

"Vamos a decir, adentro de este monte hay Nowet. $Y$ quedó asi porque, cuando se desparramaron, cada una de esas personas se fue al monte y sino al campo. $Y$ ahi mismo se hace una familia y salen personas, ya salen personas entonces; cuando nace chiquitito, ya es pesona, y asi después se va criando".

"-Pero -dijo el Quirquincho, el Padre del Quirquincho¿Por qué no me convidan una mujer, hermanos y compañeros, que ustedes que tienen dos mujeres, no van a ser capaces de dar una a este hermano, a este compañero?. No macana, él también era el Padre del Quirquincho, él, el que más sabe. No le dieron y se fue. Se arrimó a un árbol y escarbó; escarbó asi, y al ratito salió un grito de ahí: - ¡Eh! ¿Por qué me has raguñado? Y salió para el Quirquincho la mujer ésa; la que se habia disparado y escondido debajo de la tierra. Pero estaba con los ojos mal con los rasguños. Por eso ahora algunas mujeres son ciegas" (P. Yorqui). 


\section{INTRODUCCION}

Ante la perspectiva de rendir un homenaje a los 500 años de América y considerando que la ocasión es propicia para encarecer los valores espirituales de nuestra herencia indigena, tanto como para valorizar las ininterrumpidas corrientes de cultura tradicional también heredadas de Europa, optamos por lo primero en este trabajo.

Influyó también en nuestra elección de tema el hecho de vivir enclavados en una región del pais donde aún reside y anima el hombre "primitivo" o "etnológico", denominaciones que los antropólogos dan a nuestros aborigenes. $Y$ el hecho, más entrañable todavia, de que los criollos del N.E., en una proporción mayor al $50 \%$ tienen ancestros -abuelos, bisabuelos, quizás tatarabuelosindigenas, tobas, vilelas, matacos, guaranies.

Además, elegir un mito toba para un trabajo de análisis simbólicoliterario-lingüístico, podia ser un aporte a los estudios sobre literatura oral, cuyo auge es notorio en esta época. Porque los mitos indigenas son la literatura oral latinoamericana. Conocerla, interpretarla, gustarla, nos urge en este cumpleaños o quinto cumplesiglos de América.

Al principio habiamos pensado escribir capitulos introductorios acerca de la historia, ubicación geográfica del pueblo toba, sus usos y costumbres. En el transcurso de la elaboración cada uno de nosotros consideró necesario y conveniente documentarse ampliamente sobre el pueblo toba, sus características culturales, su historia, o mejor, la historia de sus migraciones y sus luchas en el amplio escenario geográfico del Gran Chaco. Entonces nos percatamos de la poca necesidad de dichos capítulos introductorios, que sólo podrian ser síntesis de obras autorizadas y conocidas por quienes se interesen en este ámbito cultural americano. Prescindimos de ellos y figuran en la bibliografia y aparato crítico de cada capitulo.

Leer los escritos dedicados a ellos acrecentó en nosotros el interés por el trabajo en sí, la estimación y por qué no, la admiración hacia estos ancestros, dignos ancestros del hombre del N.E. Supimos de su valor y coraje a toda prueba, igua que de su delicadeza y ternura para con los suyos. Nos enteramos de su solidaridad social nunca desmentida, aún cuando la civilización europea los avizoró y procuró integrarlos a su cosmovisión -empresa si no imposible, al menos sumamente difícil- . Los últimos testimonios escritos y publicados por un aborigen toba nos dicen cómo el grupo de tobas que cobró piezas de caza o de pesca comparte los alimentos con los que no pudieron obtener nada. (1)

Previa lectura de los mitos publicados hasta el presente, optamos por el Origen de las Mujeres. La importancia de este mito es indudable en la concepción del mundo toba, porque les revela el sentido ontológico de su organización familiar. Los tobas tienen pocos mitos antropogónicos conservados; el más importante y mejor conservado es éste. Su recopilación y publicación está documentada desde 1923 hasta nuestros dias. Las versiones, que tienen variantes 
de poca importancia, son narradas por los distintos informantes quienes, no obstante, conservan respetuosamente el mitema central integro.

Mientras Maria Luisa Acuña descifraba los símbolos contenidos en el mito, dejamos a Norma Porto de Farías hacer una lectura literaria y Orlando J. Genó lo inerpretaba al trasluz de la teoria de la enunciación. En el transcurso de nuestra-labor dialogábamos los integrantes del equipo y compartiamos nuestros hallazgos e interpretaciones. Desde el principio advertimos que ninguno de los tres trabajaría dentro de un terreno absolutamente propio que no debiera ser invadido por los otros dos.

Las razones de esta interpenetración temática y metodológica son obvias: estábamos trabajando sobre un pedazo palpitante de humanidad. $Y$ los tres sabiamos la importancia que la religiosidad tiene para los pueblos primitivos, para su "cosmovisión"; éste, por ejemplo, es un terreno en que nos encontramos a cada rato; igual que las cuestiones del habla; Pablo Yorqui, el informante es toba, hablante bilingüe de toba-castellano: narra en la lengua española coloquial de esta región del pais; también nuestras fuentes coṃunes inducian a una convergencia de citas, el ejemplo mayor es la publicación de Edgardo J. Cordeu, Aproximación al horizonte mítico de los tobas, estudio y colección de mitos publicados por el distinguido antropólogo en 1969-70. Nadie antes de él habia realizado un trabajo de este valor, procurándo desentrañar los puntos claves del pensamiento religioso toba. De él proviene la versión elegida para las tres lecturas. Era imposible no citarlo a veces recurrentemente en nuestros capitulos.

Como anticipo hemos presentado estos resultados en las Jornadas Interdisciplinarias sobre"Presencia de España en América: tradición y actualidad", organizadas por la Univerșidad Nacional de Tucumán y realizadas, del 11 al 14 de setiembre del año que finaliza, 1991, en San Miguel de Tucumán. Interesó al auditorio nuestro trabajo, sintesis del que ahora publicamos. A continuación el desarrollo del tema será como sigue:

- Lectura simbólica del mito, por Maria Luisa Acuña, capítulo I.

- Lectura literaria del mito, por Norma Porto de Farias, capitulo ll.

- Lectura según la teoría de la enunciación, por Orlando J. Genó, capitulo III. 


\section{CAPITULO I}

\section{LECTURA SIMBOLICA DEL MITO}

\section{INTRODUCCION}

Para mi lectura simbólica elijo el método de Mircea Eliade porque ofrece los principios y procedimientos más favorables para un buen resultado. Eliade propone una hermenéutica creadora que explicite sentidos encubiertos en los hechos religiosos, fecundando el mundo humano con renovadas simientes espirituales y posibilitando una transformación del hombre, enriquecido por valores que todavía le son ajenos.

"El mundo habla, se revela, mediante símbolos", dice el erudito rumano, "los simbolos religiosos referidos a la estructura de la vida, revelan una vida más profunda, más misteriosa que lo vital captado por la experiencia cotidiana. Tales símbolos desvelan el lado milagroso, inexplicable, de la vida y, a la vez, la dimensión sacramental de la existencia humana". "El símbolo religioso traduce una existencia humana en términos cosmológicos, manifiesta la solidaridad entre las estructuras de la existencia humana y las estructuras cósmicas. El hombre trasmuta su experiencia individual en acto espiritual gracias al simbolo". "Por ello los simbolos religiosos arcaicos implican una ontologia presistemática, expresión de un juicio que recae a la vez sobre el mundo y sobre la existencia humana. Un juicio no formulado, ni traducible en conceptos".

Vicente Fatone ha escrito, hablando de la relación hombre-Dios: "El primitivo' que se siente en comunicación con fuerzas oscuras, cuya naturaleza no alcanza a precisar, ni se detiene a escrutar, se halla ya en la plena posesión de la vida del espíritu, que consiste en no ser espectador, sino creador del mundo. Ante esas fuerzas oscuras el primitivo no se siente en relación de dependencia, como puede sentirse ante las que amenazan su subsistencia biológica. Los mitos y los ritos prueban que esos 'primitivos' se sienten responsables de toda la realidad". (1)

América aporta sus propias simientes miticas, para individualizarse y para eniquecer la cultura occidental, heredada a través de España y Europa. Los mitos de nuestra región nordeste argentina, "historias verdaderas" de tobas, matacos, pilagás, vilelas, guaraníes, revelan lo que significa el mito en la vida del hombre de la zona; pero pueden, además, enseñarnos la relación entre cultura y naturaleza, entre individuo y sociedad, $y$, en armoniosa conjunción de cosmovisiones, caracterizarnos en el contexto nacional.

"El origen de las mujeres" es un mito contado por tobas, pilagás y matacos en el Chaco. Entre los tobas ha sido recogido y publicado desde 1923 a 
1987 por antropólogos y etnólogos. Antes de proceder a la lectura simbólica del mito, me he documentado con la lectura y reflexión de las 13 versiones publicadas con interpretaciones y comentarios de sus respectivos recolectores en el lapso mencionado.

\section{FUENTES}

1) Roberto Lehmann-Nitsche publica "La astronomia de los tobas" en la Revista del Museo de La Plata en 1923; alli incluye, "Cómo los tobas obtuvieron mujeres" a la que llamo "versión $N^{2} f$ " y es una de las más parcas del mito.

2) Rafael Karsten en "Indian tribes of the Argentine and Bolivian Chaco", aparecido en Finlandia en 1932, estudia vida y costumbres de los tobas occidentales, incluye mitos recogidos entre 1911 y 1913; me aportó las "versiones $N^{0} 2$ y $3^{\prime}$, aparte de sus interesantes comentarios e interpretaciones sobre las costumbres, situación de la mujer, ceremonias de pubertad, matrimonio, comidas rituales, danzas; todo ello me sirvió para comprobar la validez ejemplar del mito y algunos simbolismos, como el del armadillo o quirquincho.

3) Alfredo Métraux en "Myths of the Toba and Pilagá indians of the Gran Chaco", aparecido en Filadelfia en 1946, me aportó las "versiones $N^{\text {o }}$ 4 y $5^{\prime \prime}$ y sus interesantes consideraciones y observaciones sobre las caracteristicas generales del folklore toba en el lapso que él los estudió. Las versiones 4 y 5 contienen elementos de magia, gracia y picardía que amenizan el mitema básico.

4) Enrique Palavecino recoge los relatos tobas entre 1936 y 1941; su esposa los publica en la revista RUNA, en Buenos Aires, 1970; me aportó la versión № 6 .

5) Edgardo J. Cordeu en "Aproximación al horizonte mítico de los tobas", publicado en RUNA, Buenos Aires, 1970. Éste es el resultado de sus trabajos de campo en Miraflores, provincia del Chaco. Discípulo de Marcelo Bórmida, Edgardo J. Cordeu considera al mito como estructura de pensamiento y de existencia, para captar el sentido de las manifestaciones culturales sobre la concepción del mundo de los tobas. Agrupa en dos ciclos las narraciones antropogónicas de Miraflores: 1) integrado por los mitos de origen celestial de las mujeres que reflejan la cosmovisión más antigua; 2) el ciclo de Metzgoshé, con rasgos sincréticos, reveladores de cómo aprehende el indigena el contacto intercultural desde el siglo XIX. Este trabajo me aportó las "versiones № 7 y 8", que en el corpus publicado por Cordeu llevan los № 70 -pertenece al ciclo 1) y en ella basamos nuestro trabajo en equipo- , y 74 que presenta Metzgoshé como antecesor y tesmóforo, transmisor de las enseñanzas de Boléh. 
El relato 70 de Cordeu, o versión № 7 mia, es una de las más ricas en picardia, gracia, recursos literarios que alargan demoradamente la historia: suma al mitema básico otros motivos míticos, como ser: 1) los Padres de los animales, 2) el origen de la pesca, 3) el vuelo chamánico del Aguila, 4) la "jefa de las mujeres" sentada en el cielo sobre la cadena, otros más.

6) J. Wilbert y K. Siimoneau en "Folk Literature of the Toba indians" editado por el Latin American Center Publications de la Universidad de California, Estados Unidos, en 1982, incluye, vertidos al inglés, todos los mitos recogidos por los autores hasta ahora nombrados. Añaden mitos tobas recogidos en 1975 por Sara Newbery, quien me aportó las "versiones 9 y 10 " que conservan el mitema básico con algunos motivos adicionales. También incluyen Wilbert y Simoneau los mitos tobas recolectados por Buenaventura Terán, entre 1975 y 1980 -y aún no publicados en 1982 cuando aparece el texto inglés- : Terán me aporta las "versiones 11 y 12", sin mayores variantes.

7) Orlando Sánchez, toba residente en Colonia Castelli de la provincia del Chaco, pastor coordinador del Consejo de Parcialidades Indigenas, publica "Antiguos relatos tobas, Togheșhic l'aqtaxanaxac na Qompi", en Buenos Aires, 1987. Es un texto dividido en dos partes, la primera contiene en lengua toba los relatos recogidos de ancianos tobas residentes en Chaco y Paraguay; la segunda parte del libro contiene la versión castellana de dichos relatos, traducción hecha en colaboración entre Orlando Sánchez y $\mathrm{H}$. Wynarczik, sociólogo nacido en J.J. Castelli pero residente en Buenós Aires. Este libro me aportó la "versión № 13", interesante no sólo porque documenta la vigencia del modelo mítico en nuestra época, sino también porque muestra cómo la religión pentecostal, vigente en dicho grupo toba y lugar, ha hecho aportes del simbolismo del fuego, dentro de la narración toba. Queda patente cómo el simbolismo religioso del mito sobre el origen de las mujeres, admite lecturas algo distintas en cada época y acoge los cambios en la religiosidad de los miembros de la colectividad en que se da.

\title{
DESARROLLO
}

\begin{abstract}
Centramos nuestra lectura simbólica en la versión $N^{2}$-o relato 70 según Cordeu- . Presentamos el mito en cinco secuencias con sus respectivas interpretaciones

Primera secuencia: los hombres viven solos, dedicados a sus trabajos. Un dia al regresar a su casa, descubren que su comida ha desaparecido, que han sido robados. Resulven dejar como guardián al Loro. Este oye un ruido, mira en torno
\end{abstract}


para saber de dónde viene y descubre que se origina en el cielo. Ve bajar en un hilo o cadena -el narrador dice: "Eran no sé cuántas las mujeres que venian en ese hilo, vamos a decir que es hilo pero es cadena; parecia un hilo y es largo ese hilo"- a las mujeres.

Interpretación: el cosmos toba tiene tres regiones: cielo, tierra (con dos subregiones, campo y monte) y profundidades (con dos subregiones, terrestre y acuática). Cada región del espacio está sometida a un Señor o a una Pareja Principal, quienes gobiernan a los Dueños o Padres de los Animales que habitan la misma.

El cielo y la tierra entran en comunicación por la bajada de las mujeres asidas a un hilo, cadena o cuerda, según otras versiones. Hay un "centro" creado por esa "ligazón". En torno a la imagen de la "cuerda" o "hilo que liga al hombre a las regiones superiores, Eliade tiene un estudio abarcador de una amplia geografia en la cual se despliega un rico complejo simbólico.(3) El "hilo" nombrado por Yorqui, informante de Cordeu, permite la comunicación de niveles cósmicos; pero es una imagen ambivalente: las mujeres tienen una situación privilegiada porque vienen de un ámbito celeste donde habita Dios; sin embargo su situación es de sojuzgamiento, porque están ligadas, encadenadas. Según Yorquí son enviadas por Dios para compañeras de los hombres, pero desobedecen el mandato (4). La situación de dependencia está clara en las versiones № 2 y 3 : las mujeres bajan encerradas en una caja o jaula pendiente de una cuerda, y gritan pidiendo ayuda a los hombres para liberarse.

Segunda secuencia: las mujeres roban la comida, lastiman al Loro y retornan al cielo. El segundo guardián elegido es el Aguila, con perfiles de piogonak, hombre y ave, poderoso, sabio, Oye un ruido fuerte y ve bajar a las mujeres, les impide robar, sigue una lucha en el espacio entre el Aguila, que vuela cada vez más alto huyendo de los ataques de las mujeres asidas a la cadena, hasta que, alcanzada la altura precisa, el Aguila corta con su machete la cadena y las mujeres caen. Sólo una se entierra al pie de un árbol.en las versiones № 1-6, 9, 10 y 13 las mujeres caen y pasan al tercer nivel quedando enterradas.

Interpretación: la acción del Aguila es un modelo para alcanzar el poder chamánico, su vuelo ascendional munido de su machete afilado, la lucha con las mujeres uránicas, el corte de la cadena en un sitio preciso del espacio -en un "centro" lo hacen piogonak. Este sería uno de los motivos míticos enriquecedores del mito en análisis. La caída de las mujeres desde el espacio celeste a la profundidad terrestre equivale a una muerte simbólica.

Tercera secuencia: Aguila llama a gritos a sus compañeros que acuden corriendo; pero se les atraviesa una gran vibora amenazante. Los hombres más ligeros, Xuri, Chuña, Guasuncho, saltan y pasan. Los demás esperan al Quirquincho, porque él tiene caparazón. Yorqui caracteriza al Quirquincho: "Un viejito que le dicen Quirquincho porque siempre viene atrás, porque es un hombre 
chiquitito...". Llega el esperado y sufre el ataque de la vibora que le pica hasta que se le rompen los dientes, y pasan todos.

Interpretación: Eliade define a la serpiente como epifania lunar, vinculada con lá mujer y la fecundidad; tiene muchas valencias simbólicas; pero la idea central la hace dispensadora de fecundidad, ciencia (profecia) e inmortalidad.

La víbora atravesada en el camino hacia las mujeres forma un cruce simbólico de un cambio de dirección que está por producirse: La víbora trảnsfiere fecundidad, ciencia e inmortalidad al Quirquincho; una transferencia de poderes.

Cuarta Secuencia: el Aguila entrega dos mujeres a cada hombre animal, menos al Quirquincho. El Padre de los Zorros, Juan, ansioso, se une a una mujer y queda mutilado; recompone su anatomía. Aguila destruye los dientes vaginales de todas las mujeres; se forman las parejas.

Interpretación: Cordeu sugiere un entronque sabártico del motivo de la vagina dentata y concluye su interpretación diciendo: "Es significativo que en coincidencia con la primera cópula en la que a diferente nivel, intervienen distintos planos del espacio y por primera vez, seres de sexos opuestos, tengan lugar la escisión e individualización de la primera creación y la consiguiente aparición de los dueños de las especies, y por ende el fin del tiempo del mito":

Podemos sumar el simbolismo de los dlientes, armas de ataque primigenias, cuya pérdida es un simbolismo negativo, porque significa una derrota o inhibición. Cirlot menciona la existencia de "interpretaciones que recargan el significado en la parte sexual de la energia". Ambos significados se dan en este mito. El Aguila impone templanza a hombres y mujeres.

Quinta secuencia: el Quirquincho queda solo; reclama, nadie te responde; él se aproxima al pie del árbol donde estaba escondida la mujer que se había escapado; empieza a cavar y oye un grito, ha lastimado los ojos de la mujer que sale y es la suya. Yorqui termina explicando que por esta acción hay ahora algunas mujeres ciegas.

Interpretación: en la mayor parte de las otras doce versiones del mito analizado, el Quirquincho, Tatú o Armadillo ayuda a sacar mujeres debajo tierra al Carancho, Boléh, también Holé y Wolí, nombres de las distintas versiones. El Quirquincho como cavador de mujeres falta en las versiones $1,2,3,8$; pero está en todas las demás. Falta en las versiones con sincretismo; las recogidas por Karsten entre los tobas occidentales evangelizados por sacerdotes franciscanos son las № 2 y 3; la 8, recogida por Cordeu es del ciclo de Metzgoshé.

Esta secuencia complementa a la segunda como simbolismo: la caída es la muerte y el desenterramiento es un renacimiento; ambos son pasos de una iniciación. Caben dos interpretaciones: 1) al ser sacadas de la profundidad las mujeres quedan ciegas, en otros casos tuertas. Esta acción de cegarlas sería para conjurar la peligrosa sabiduria de las mujeres, tanto por su origen uránico, como 
por haber conocido el nivel subterráneo del cosmos. Esta sabiduria seria peligrosa para su vida con los hombres. A diferencia de los iniciados que adquieren conocimiento y sabiduria, superando su condición de hombres comunes, las mujeres celestiales, uránicas, sabias, olvidan casi totalmente su sabiduria, para vivir en la tierra; pero en compensación por la pérdida de la vista o de un ojo. alcanzan un bien mayor: el misterioso poder de generar vida. 2) el Quirquincho al ser picado por la vibora recibe sus poderes totalmente, ella queda sin dientes; él aumenta su sabiduria y al desenterrar a las mujeres les transmite este poder, que es tanto la fecundidad como el secreto de la vida. En ambas interpretaciones, hay un acceso a la espiritualidad y una "feminización" de las mujeres uránicas, perdido ya el rasgo de anatomia monstruoso y adquirida la fecundidad.

Conclusión: la vigencia ejemplar del mito ha sido comprobada y comentada desde fines del siglo $\mathrm{XIX}$ hasta nuestros dias, especialmente con referencia a la monogamia y abstinencia después de celebrado el matrimonio, por un breve lapso. Explicitamente lo comentan Karsten, Métraux, Cordeu, Sánchez. El documento de fines del s. XIX, es una obra del P. Cardús, citada por Karsten por otros motivos; pero en la cual nosotros encontramos la vigencia del mito en la ceremonia posterior a la aceptación del pedido de mano, entre el novio y la novia, que recuerda el relato del origen de las mujeres (6). Karsten comenta que las danzas tobas ayudaban a mantener el equilibrio cósmico en el grupo y describe una nupcial, la llamada Nahotti, en la cual vemos el fuerte recuerdo del mito. Por otra parte, aunque no estuviera documentado el ritual, es una constante en la vida de los tobas la consideración y respeto que tienen por sus mujeres en la vida cotidiana.

Por todo lo dicho concluimos que este mito revela un tránsito ontológico y fundante para los dos sexos: tas mujeres alcanzan su feminización como dijimos y los hombres-animales, alcanzan su forma definitiva, se "hominizan", pierden su animalidad predominante, igual que su sexualidad exacerbada, se espiritualizan. Es un mito de tránsito, porque los hombres presos en su animalidad y las mujeres uránicas encadenadas a un ámbito no humano, se buscan y alcanzan juntos su dimensión personal, creciendo ambos en humanidad, al aprender la moderación y templanza para vivir como personas. Lo dice el informante de Cordeu, Pablo Yorqui:

"Y ahi mismo se hace una familia y salen personas, ya salen personas entonces; cuando nace chiquitito, ya es persona, y asi después se va criando". Ha terminado el tiempo mitico y empieza a crecer la nación toba.

Resistencia, 1.5 de julio de 1991

Maria Luisa ACUÑA 


\section{CAPITULO ॥}

\section{LECTURA LITERARIA DEL MITO SOBRE EL ORIGEN DE LAS MUJERES}

Para la lectura literaria del mito se ha tomado la versión recogida por Edgardo J. Cordeu en la localidad de Miraflores; Provincia del Chaco, entre junio de 1966 y noviembre de 1967. El informante es un toba bilingüe P. Yorqui, y el investigador ha corregido la expresión sólo cuando era incomprensible. Se ha elegido esta versión por considerarla la mejor estructurada desde el punto de vista expresivo de la narración.

La sintaxis del relato sigue la secuencia lineal del cuento tradicional: a) Introducción: ubicación temporal "in illo tempore", b) nudo: llegada de las mujeres desde el cielo, c) desenlace: formación de parejas entre seres y mujeres primigenios de donde nacen las distintas especies y con la que concluye el tiempo mitico.

En la introducción, bastante extensa, la intención de precisar el tiempo mítico va acompañada de una indicación sobre el espacio y formas de vida de los origenes; se destaca la ausencia de mujeres, la fuente alimenticia de pervivencia (la pesca), las caracteristicas de esos seres de configuración mixta, parte animal, parte humana y su sentido gregario de comunidad: "En ese dia se empezaban a juntar esas gentes".

El hombre Aguila, héroe del relato y héroe benefactor de la humanidad, estä presentado ya en esta parte introductoria con sus atributos de poder, el espíritu y su capacidad de elevación como potencia celeste.

La llegada de las mujeres se realiza en un contexto "agonístico", de lucha; el móvil del descenso es el robo y los hombres deben defenderse.

Se suceden tres episodios en esta contienda: 1) los reiterados intentos de robo con la captura final de las mujeres, 2) el dificultoso regreso de los hombres que habian ido de pesca, 3) finalmente el peligro que deben vencer antes de la cópula, la temible vagina dentada, y la distribución de las mujeres.

La secuencia narrativa se quiebra a veces con digresiones explicativas, como las interpuestas después de la primera asamblea de nombres y antes de la segunda, donde el relator explica el origen de las especies cada una con sus Dueños o Padres, la desobediencia del mandato divino por parte de las mujeres y el modelo ejemplar de los seres de la temporalidad originaria:

"Estaban el Padre del Guasuncho, la Madre del Guasuncho, del Chancho, de todos esos bichos. ¿De dónde viene esa gente?; pero son todos hombres, Padre por Padre". 
"Yo creo que el Dios manda a esas mujeres para que los otros las agarren y se queden también con ellas. Pero ellas no se presentaron como si vinieran a querer quedarse, sino que vienen a robar".

"...esa gente pescaba; entonces nosotros, los viejos, hemos seguido a esos pescadores de antes".

Después del desenlace, diseminadas ya las parejas y formado el género humano, el narrador se acuerda del Quirquincho que ha quedado sin compañera. Como a él se le niega su pareja, escarba la tierra para desenterrar la que se había escondido alli. La mujer grita y protesta porque el Quirquincho le ha rasguñado los ojos:

"Se arrimó a un árbol y escarbó asi, y al ratito salió un grito de ahí: - - Eh! ¿Por qué me has rasguñado?.

De esta forma termina el relato de manera menos solemne, en un contexto vital de acción y con rasgos de humor.

El relato obedece a las características propias de las narraciones de las culturas orales cuyos elementos se tratarán de desentrañar: estilo copioso, redundante, con exceso de verbosidad y estructuras paralelas, adjetivación escasa pero con expresiones calificativas, períodos breves que prefieren la acumulación de la parataxis en contraposición de las formas racionalistas de la hipotaxis.

Walter J. Ong (1) analiza la psicodinámica de la oralidad señalando que las culturas orales estimulan la fluidez, el exceso, la amplificación. De ahí el estilo copioso, redundante de estas narraciones orales con mucho estilo directo y "dice" intercalado, con mezcla constante de presentes y pretéritos que le otorgan al relato vivacidad, gracia y plasticidad:

"Gritaba y gritaba el hombre para llamar a los otros:

- ¡Qué vengan, que venganl ¿Y quién iba sentir ese grito?, no lo sienten. $Y$ al rato una lguana que venía atrás, ¿quién iba a creer que la iguana. que camina abajo, oyó un ruido?, el grito ese.

- Bueno -a los otros compañeros- ipárense!, que he sentido el grito que gritaba ese.

- Que va a ser -dijo uno- yo no he oído, yo que estoy parado más alto que vos ¿Qué va a oír el hombre que está siempre abajo!

- Bueno -dijo la lguana-, perdoná compañero.

Al rato paró esa gente y quedó quietito. Al ratito pegó otro grito el Aguila y entonces lo escucharon:

- Ahí están -dicen-, ya ha sido el grito.

Ya se viene esa gente a todo lo que da, era como si fuera a correr una pelota; desnudos venían, no tenían nada porque estaban en el agua". 
Como toda la tradición oral, la narración lleva una carga de epitetos, escasos adjetivos que se repiten para calificar al personaje tipificándolo: El Loro, primer guardián, vencido y azotado por las mujeres, es el "pobre viejo"; el Aguila, el héroe, "poderoso y saberoso"; el Quirquincho, el vencedor de la víbora, "el que más. sabe".

El estilo reiterativo y acumulativo del lenguaje oral se organiza en forma paratácticas, simples formas de yuxtaposición. "El discurso escrito despliega una gramática más elaborada y fija que el discurso oral, pues, para transmitir significado, depende más sólo de la estructura lingüistica, dado que carece de los contextos existenciales: plenos mormales que rodean el discurso oral y ayudan a determinar el sionificado en éste. de marera un noco indenendiente de la gramática". (2)

"Que esa gente que era de ese tiempo. Bueno, ese día se empezaban a juntar esas gentes y no tenían mujeres; nada, todos esos eran varones! Y habia ¿Qué voy a decir?, había un campo lleno de agua y pescado; que esa era su vida, que en esa vida estaba esa gente. Pero sin mujeres, todos eran varones".

"¡Y en el camino se atravesó una, un pedazo de víbora. asi. como si fuera alta asi; una víbora, tremenda viboral, se atravesó".

En el primer ejemplo se suceden oraciones de estructuras muy simples, una junto a otra y una idea que se repite insistentemente en un fragmento breve, - la falta de mujeres: "y no tenian mujeres", "nada, todos esos eran varones, pero sin mujeres, todos eran varones!."

En el segundo, la víbora es el obstáculo que encuentran los hombres que regresan al escuchar el llamado del Águila. La narración es animada y con movimiento. Como en tropel los hombres intentan el camino de retorno hasta que se interpone en su paso la vibora. El relator quiere reflejar la magnitud del animal y recurre a la reiteración acumulativa y a los ademanes, "asi", "como si fuera alta asi". El significado está dado por otro tipo de lenguaje más que por el lingüístico.

La composición presenta características comunes con otras narraciones tradicionales y que el folklorista danés Oxel Orik las enunció como "leyes épicas".(3)

a) Ley de la apertura y del cierre: el relato no comienza bruscamente ni termina de modo abrupto, sino que se mueve de la calma a la agitación, y luego retorna a la calma.

De una descripción introductoria del tiempo mítico pasa a la contienda con las mujeres que aún vencidas mantienen su peligrosidad por la vagina dentada. Cuando puedan solucionareste problema, se produce el desenlace en un clima de sosiego, logrado por la placidez que surge de la formación de parejas. Como anteriormente se anotó, después del desenlace queda aún un momento de 
tensión, el Quirquincho que reclama a su mujer, pero pronto se serena cuando él consigue su objetivo.

b) Ley de la repetición: "en la literatura oral el medio efectivo de enfatizar es la repetición (de acciones, diálogos, personajes)".

"En gran parte de las narraciones folklóricas europeas, esa repetición se debe a la ley del tres (tres hermanos ejecutan sucesivamente las mismas acciones, concesión de tres objetos mágicos, tres deseos, etc.). Pero no en todas partes se aplica esta ley, por cuanto el número está ligado a concepciones religiosas que no son universales". (4)

En el relato de Yorki se establecen esquemas duales. Se forman dos asambleas para resolver el problema del robo, como consecuencia de estas deliberaciones se dejan sucesivamente dos guardianes, el loro y después el águila que debe anunciar dos veces su triunfo antes de ser escuchado. El cruce peligroso de la víbora se hace en dos tandas, los más ligeros logran eludir el peligro, pero los otros deben esperar a que el Quirquincho consiga derrotar al reptil. Se entregan dos mujeres para cada uno. En el reparto se producen dos incidentes que rompen con la placidez del triunfo: el de Juan, el Zorro, quien por apurado e intempestivo intenta copular sin advertir, a pesar de los consejos de los demás, que la vagina de las mujeres posee dientes; y el del Quirquincho, quien, por lento, llega tarde y tiene que procurarse él solo su pareja.

Los episodios de los dos intentos de robo tienen un paralelismo total, difieren, por contraste, en el resultado de la lucha: 1) asamblea dehombres, 2) elección del casero, 3) retirada de la comunidad que va de pesca, 4) la señal del ruido, 5) descenso de las mujeres por un hilo, 6) discusión con las mujeres que piden comida, 7) agresión a cascotazos y palos. En el primer caso las mujeres subyugan al Loro y en el segundo el Águila logra cortar el hilo y las mujeres caen.

c) Ley de la unidad de la trama y concentración en un solo conflicto: El relato posee unidad en la trama y se centra en un conflicto: la necesidad de reprimir a las mujeres para procurarse pareja.

Señala Walter Ong que "En ausencia de categorias analíticas complejas que dependen de la escritura para estructurar el saber a cierta distancia de la experiencia vivida, las culturas orales deben conceptualizar y expresar en forma verbal todos sus conocimientos, con referencia más o menos estrecha con el mundo vital humano, asimilando el mundo objetivo ajeno a la acción reciproca, conocida y más inmediata, de los seres humanos". (5) Es un mundo de acción que al mantener engarzado el conocimiento en lo vital humano se expresa en un contexto de lucha: frases hirientes al rival, insultos reciprocos, competencias.

En este contorno de pugna, con matices agonisticos, se desenvuelve el episodio central. La actitud de las mujeres es siempre provocativa, vienen a robar y están armadas. Se presentan como uha cratofania uránica precedidas por un estrépito. La contienda va antecedida por un duelo verbal que es más extenso la segunda vez pues el Aguila le opone una resistencia tenaz:

- ¿No se puede convidarnos a nosotras?. 
- Pero mirá hay que esperar a los compañeros, entonces todos las convidaremos a ustedes...

- Pero carajo, usted es mezquinoso.

- Pero no -dijo el Águila. Y no quiso convidar ni un pedazo.

- I Bueno, si usted mezquina las cosas para comer, entonces te mataremos, te mataremos!.

- Y bueno, háganlo si ustedes buscan eso, ¡Háganlo, yo no disparol.

La actitud de desafío se repite en otros incidentes. La Iguana escucha el primer anuncio del Águila, pero sus compañeros no le creen y la retan.

El pasaje de Juan, el Zorro, mantiene estas características agonisticas con matices diferenciales y agrega una nota de humor al relato. La actitud de Juan es de un desafío ingenuo, inoportuno, y de arrebato necio. El Zorro padece las consecuencias de su impetu insensato. El relator resalta su terca obstinación; el Zorro, a pesar de las advertencias, va confiado a tomar su pareja. El primer intento de cópula fracasa por el desenfado de Juan que se niega a escuchar el peligro que entraña lo desconocido, el tabú de lo maculado. Las mujeres atraen, pero son peligrosas.

La narración adquiere vivacidad por la posición del narrador que participa emotivamente del relato, a veces como vocero del alma comunitaria, y por la relación congregante relator-oyente.

Sostiene W. Ong que las culturas orales son "empáticas y participantes antes que objetivamente apartadas". Para ellas "aprender a saber significa lograr una identificación comunitaria empática y estrecha con lo sabido, identificarse con él. La reacción del individuo no se expresa simplemente como individual o subjetiva, sino como encasillada en la reacción, el alma comunitaria" (6).

Esta identificación afecta la gramática de la narración ya que el narrador irrumpe en el relato con acotaciones expresivas emocionales, con movimientos corporales o matices de entonación.

Lo llevaron todo, ni nada dejaron; que se les había antojado a esas mujeres ir a buscar y llevarse esa comida, jca!.

Y claro, el Loro desconfió y al rato se retiró; pero ya las otras alzaban cascotes para garrotearlo, y se voló; claro tiene que disparar el pobrecito.

La interjección ca demuestra el enojo del narrador por la actitud de las mujeres. Disgusto manifestado también más adelante en el comentario "Pero no, quieren disparar las mujeres, asi nomás quieren hacer; siempre tienen que hacer asi y van a robarlo". En el segundo ejemplo el narrador se compadece del Loro azotado "claro tiene que disparar el pobrecito".

Gritaba y gritaba el hombre para llamar a los otros: ¡Qué vengan, que venganl ¿Y quién iba a sentir ese grito? no lo sienten. $Y$ al rato la lguana que venía 
atrás; ¿quién iba a creer que la lguana, que camina abajo, oyó un ruido? el grito ese.

El relator comparte la acción como si estuviera presente, identificándose con aquellos que no escuchan el llamado.

A veces el narrador lo cuenta como una sabiduría transmitida por generaciones: "Al rato dicen que el pobre viejo sintió un ruido", y a veces utiliza la primera persona como un saber aprehendido y sentido no sólo por él sino por toda la comunidad: "Eran, no sé cuántas, las mujeres que venian en ese hilo, vamos a decir hilo, pero es cadena, parecía un hilo y es largo ese hilo.

El relator no se olvida de su oyente y trata de integrarlo. El lenguaje mímico ayuda al lingüístico oral: "ya venian', y parecian un tiro así, mirá vos, todas formadas en fila". "Que me vas a creer vos que cuando bajaron esas mujeres, una entró en la tierra y está escondida ahí abajo?. Ahi está abajo de la tierra".

En la narración el relator, la realidad y el oyente se funden para producir una notable sensación de vitalidad. Yorki participa activamente en lo que narra, se introduce en el mundo narrado; junto a él, el oyente, incorporado, vive también intensamente los hechos y situaciones.

A través de este intento de análisis vemos que, aún dentro de la aparente sencillez y estilo de oralidad, el relato plasma una atmósfera de tensiones en "crescendo" que le confiere fuerza dramática ya que como todo relato de las culturas orales utiliza los conceptos en marcos de referencias situacionales y operacionales que lo mantienen dentro de un mundo vital. 


\section{CAPITULO III}

\section{LECTURA SEGUN LA TEORIA DE LA ENUNCIACION}

En esta sección analizamos una variante del mito que trata del "origen de las mujeres" y, consecuentemente, de la "humanidad (toba)" (1), al trasluz de la moderna teoría de la pragmática enunciativa y mediante un procedimiento hermenéutico que nos revele mejor el marco espacio-temporal (aquí-ahora) del momento justo de la interacción comunicativa entre el emisor (un aborigen informante) y el receptor (un antropólogo argentino) y que, a la vez, nos permita evaluar el grado de participación (adhesión, creencia, convencimiento) de los actantes (sobre todo del sujeto-enunciador) en relación con los hechos (míticos) narrados. Es claro que, antes, debimos despejar las complicaciones metodológicas con que tropezamos desde el comienzo mismo de nuestra investigación.

Al principio, nomás, el intercambio comunicativo en el que afincábamos nuestro análisis se nos esfumó tras el unipersonal relato del informante de la versión elegida. Sin embargo, a poco andar y siguiendo rastros lingüísticos patentes (a los que nos referiremos más adelante), pudimos revelar, restituir el diálogo latente, ameno e informal que discurre bajo el silencio-cómplice (incluso programado) del antropólogo investigador, asi como discurre bajo todo acto de habla. "El lenguaje es por esencia diálogo -nos recuerda Ortega y Gasset- , y todas las otras formas de hablar depotencian su eficacia" (2).

Simultáneamente, nos cuestionamos este otro dilema: si el lenguaje de los nativos consiste más en un modo de acción social que en una mera transmisión de datos e ideas, ¿cómo verificarlo en un monólogo a través del cual un aborigen bilingüe cuenta un mito a una persona extraña a su cultura, fuera de las condiciones necesarias que le imprimen validez, tales como 'lugar, tiempo y circunstancias propicios', esto es, al margen del lapso sagrado a que alude Mircea Eliade(3). Pero, afortunadamente, nos encontramos con estas reflexiones de Malinowski: "(...) las palabras de un cuento son significativas debidas a las experiencias previas de los oyentes; y su significado depende del contexto de la situación a que se refieren (...); el lenguaje narrativo es derivado de su función y sólo se refiere indirectamente a la acción, pero la manera en que adquiere su significado sólo puede comprenderse partiendo de la función directa del lenguaje en acción" (4).

Entretanto, no dejaba de preocuparnos la validez testimonial de la variante elegida por el hecho de estar expresada en español subestándar, dialecto que hablan los nativos aculturados de la zona en que vivía el informante; tal vez si la hubiéramos seleccionado en lengua toba habria sido apreciada por los 
etnolingüistas; pero, dados los objetivos propuestos (entre los que cuenta nuestro deseo de homenajear al idioma castellano en el quinto centenario de su llegada a América), una opinión de Marcelo Bórmida al respecto nos resultó decisiva; precisamente aquella que nos asegura que no existe "una diferencia fundamental -en su carácter de fuente- entre un texto en idioma indígena con traducción - interlineal y el relato que pueda proporcionarnos un aborigen que domine suficientemente una lengua occidental. Los problemas $\theta$ inconvenientes de la 'traducción' son básicamente los mismos, y quizás menores en este último caso, pues el informante hará lo posible para adaptar el pensamiento indigena a la expresión castellana o inglesa; no lo conseguirá sin duda, como no lo conseguirá la traducción del mitógrafo más experimentado, pero el relato tendrá la ventaja de ser pensado, expresado y aclarado en parte por la misma persona" (5).

Todavia nos quedaba por afianzar nuestro convencimiento sobre la fiabilidad de la hipótesis que sustentábamos, o sea, develar la conciencia mítica del informante reconociendo -según recomienda Kerbrat-Orecchioni- "los procedimientos lingüisticos (shifters, modalizadores, términos evaluativos, etc.) con los cuales el locutor imprime su mensaje (implicita o explícitamente) y se sitúa en relación con él"(ø). Pues bien, confiados en poder lograrlo aunque sea en parte. nos decidimos a efectuar el análisis sobre la base de los dos niveles enunciativos: por un lado, el contextual, en el que reseñaremos la situación sociocultural del informante en el momento de la relación del mito $y$, por el otro, el co-textual o textual propiamente dicho, en el que rastrearemos los indices formales que nos aproximarán a su conducta mítica.

La versión elegida corresponde textualmente a un informante bilingüe (toba-español) llamado Pablo Yorqui, de cincuenta y cuatro años al momento de la información, poblador toba de Miraflores (pequeña localidad ubicada en el noroeste de la Provincia del Chaco); a su vez, recogida in situ por el prestigio antropólogo argentino Edgardo J. Cordeu entre los años 1966-1967 (no precisa la fecha); y publicada en RUNA, revista especializada del Instituto de Ciencias Antropológicas de la Universidad de Buenos Aires $(\pi)$.

"Miraflores - nos informa el mismo Cordeu- se encuentra ubicado $43 \mathrm{Km}$. al N.O. de la localidad de J.J.Castelli -zona montaraz, de clima inhóspito y suelo duro, agregamos nosotros- ; está incluido en el seno de un frente de colonización relativamente reciente, compuesto por poblaciones criollas y otras de inmigrantes centroeuropeos y sus descendientes. Habitan alli algo más de 600 indigenas (entre los que se cuenta el informante Pablo Yorqui) relativamente sedentarizados, merced a cultivos algodoneros subvencionados oficialmente" (8).

La población indigena de la zona todavía convive con criollos y extranjeros pero manteniendo contactos esporádicos sobre todo, como dice Elmer S. Miller, "con patrones, esto es, plantadores de algodón, administradores de obrajes o de ingenios azucareros, y otros que ofrecen trabajo temporario; con los 
bolicheros (dueños de almacenes), quienes venden comida y provisiones a los Tobas, y les compran a veces algodón y otras cosas a cambio; con representantes gubernamentales de la administración para los aborígenes, quienes suministran crédito y mercancías en áreas estratégicas, compran algodón a los Tobas, y manejan la mayoría de los problemas de tenencia; con misioneros protestantes extranjeros, algunos de los cuales hablan toba, y que visitan regularmente las comunidades tobas; contactos más informales con criollos y ciudades del Chaco; con algún investigador social de Buenos Aires o de algún centro universitario" (9). Pues, la aculturación del aborigen de Miraflores se debió más a esa forzosa convivencia que a una programada instrucción. Sólo las últimas generaciones asisten parcial e irregularmente a escuelas primarias, algunas dependientes de iglesias cristianas de gran arraigo en la zona. En este sentido, las evangélicas oriundas de los Estados Unidos (principalmente el pentecostalismo) influyeron en la modificación de ciertas creencias y costumbres mediante cultos religiosos adaptados a ritos ancestrales de los tobas. Asimismo, su visión de la cultura de occidente siguen siendo tan fragmentaria como en los comienzos de la colonización, cuando varones atípicos (exploradores, soldados y sacerdotes) llegaron al Chaco sin sus familias y sin otras pretensiones que las de explotación y evangelización. Con todo, la pregonada integración de los indígenas a la comunidad nacional no deja de ser todavia una manifestación de anhelo (19).

Flagrante producto de tal proceso de aculturación es también la adquisición por parte de los aborigenes del lugar del español subestándar que hablan como segunda lengua. Se ha promovido asi una situación de bilingüismo (toba-español) muy conflictiva en el orden educacional y administrativo, pero sumamente útil para la interacción diaria y para la investigación antropológica, sobremanera lingüistica (dialectal). Sin embargo, en esta misma área, se reconoce que tal bilingüismo, aparte de cierto intercambio léxico, no ha ocasionado serios problemas de interferencias fónicas, morfológicas, sintácticas o semánticas, como las que provocara el fenómeno bilingüistico del guarani-español en la conformación de la lengua subestándar todavía vigente en la inmensa región del nordeste argentino y, particularmente, en el relato del informante Yorqui. A dichas interferenciás hay que agregar todavia las peculiaridades del castellano en la Argentina (en especial, de la región nordeste) y todo el fárrago de incorrecciones e impropiedades que, desde el punto de vista de la norma culta, menudean en los niveles informales de la lengua española (regional, vulgar, familiar, jergal, rural, etc.), favorecidas todas por las inmigraciones de europeos en general y por las constantes transmigraciones de provincianos argentinos en particular, hablantes todos de idiomas extranjeros, o bien, de español inculto. Pero, de paso, recordemos que no son éstas las señales lingüisticas que aquí nos interesan.

En realidad, ya lo dijimos, nuestro verdadero cometido es analizar los operadores enunciativos que contribuyen a evaluar el grado de participación mítica 
del informante Yorqui en el momento de la enunciación del mito. Por eso, antes del estudio pormenorizado, conviene aclarar que la canónica situación enunciativa del "yo-tú/aqui/ahora", en el caso particular del relato yorquiano, se desdobla en "yo-tú//él (enunciador-enunciatario//mito enunciado)/aquí//ahí (espacio enunciativo//espacio mítico enunciado) /ahora//antes (tiempo enunciativo// tiempo mítico enunciado)". Pues, éste es el orden que seguiremos en nuestro análisis.

"Enunciador-enunciatario//mito enunciado". Según lo anticipamos, la situación enunciativa de la variante seleccionada deviene muy especial: una de las razones se debe a que el enunciador se extiende en un largo monólogo como confirmando aquella hipótesis de Bajtín: "Este excedente de mi visión que siempre existe con respecto a cualquier otra persona, este sobrante de conocimiento, de posesión, está determinado por la unicidad y la insustituibilidad de mi lugar en el mundo: porque en este lugar, en este tiempo, en estas circunstancias yo soy el único que me coloco alli; todos los demás están fuera de mí" (11). Así, durante su relato, Yorqui suelta permanentemente señales lingüisticas que verifican su privilegiada, aunque intuitiva, posición:

a) La primera persona del enunciador aparece marcada por pronombres personales (tanto subjetivos como objetivos), por 'morfemas flexivos verbales y también por formas gramaticales, incluso locuciones clisés, de primera persona del plural equivalentes a la primera del singular, frecuentemente para manifestar el convencimiento experimentado por Yorqui, 0 , al menos, su personal interpretación o creencia:

"Yo creo que el Dios manda esas mujeres (...)"

"Que me vas a creer vos (...)"

"(...) entonces nosotros, los vieios, hemos seguido a esos pescadores de antes $(\ldots) "$.

b) En otras ocasiones, tal primera persona no evidencia sólida convicción, sino, por lo contrario, revela las desconcertantes dudas de un aculturado por compulsión político-religiosa de la época que Yorqui debió padecer; dudas que se manifiestan, sobre todo, a nivel de la conciencia mítica; es aquí donde surgen replanteos que, de no haber influido las iglesias cristianas y, más aún, la civilización europeizada del mundo occidental, seguramente no se habrían formulado:

"Y se junta esa gente; no sé si será Dios que los hace juntar". (¿cómo no sabe?; ¿el Dios de los cristianos o el de los tobas?).

"Eran no sé cuántas las mujeres que venian en ese hilo, vamos a decir hilo pero es cadena" (¿hilo o cadena?; ¿tal vez porque la cadena. producto del hombre civilizado, es más resistente?).

c) Creencias y convicciones, dudas y desconciertos ocurren tambien en segunda y tercera persona, cuando no, en forma de interrogantes o de aseveraciones categóricas, inclusive de interjecciones y onomatopeyas; todo dicho con el 
tono más enfático y popular, tan convincente como pintoresco; tono que, a la par de enfervorizar, vigorizar la expresión, remarcan la subjetividad del enunciador:

"Si vos tenés un loro, sale una persona si es que puede hablar ese loro" (aqui la.segunda persona equivale más a una primera -si yo tengo un loro- o a una tercera -si uno tiene un loro-. , ambas formas con sentido de persona indeterminada). "Al rato, dicen, que el pobre viejo sintió un ruido" (¿por qué dicen?, como si repitiera algo que accidentalmente se le hubiese contado).

"¿De dónde viene esa gente?... "que de dónde salen todos esos bichos?... ¿que de adónde sale esta gente?" (por qué estos interrogantes?, si antes el mismo Yorqui había dicho: "eran personas, como en forma de Nowet; todos salen de ése, de ése era esa gente").

"Zas! y se cayeron esas mujeres".

"...pero ¡carajo Señoral (dice uno de los personajes del mito), yo no puedo darles la comida".

"Un ruido que parecía un cañón fuerte, un ruido fuerte, jbrum, brum!".

d) Esta condición de aborigen aculturado que aún no se desembaraza de la etapa de expresión sensible-intuitiva a que alude Cassirer, durante la cual "no es mera meditación sino la acción la que constituye el eje de donde comienza para el hombre la organización espiritual de la realidad" (12), esta condición es la que impulsa al enunciador a que atribuya jerarquías, actividades, o les hace decir modismos, apelaciones, conceptos en general extrapolados del entorno regional, a personajes y otros elementos del mito que trata, nada menos, que del origen de la humanidad (toba), recurso impremeditado que le restituye color local al relato:

"¿Qué, a quién vamos a dejar acá? ...jeso, un caserol".

"...él es el que maneja esa gente, es el comandante de la pescada".

"Las mujeres tenían... una capataza" (una de las mujeres que lideraba el grupo).

"Entonces dijo la maestra, la directora" (la misma mujer que lideraba el grupo).

"Estaban los otros dele cazar pescados".

"Juan dijo: - - Qué carajo que me cortaron el pingol".

"Y ya se viene esa gente a todo lo que da".

"El loro estaba así... por un cascotazo que le garrotearon en la cabeza".

"...y cuando lo quieren joder se va".

"...jbajl, sonó el pobre".

"...los otros vuelta otra vez a cazar pescados".

"No macana, él también era el Padre dẹl Quirquincho".

e) Pero, indudablemente, los índices que mejor revelan la adhesión emotivo-religiosa de Yorqui son los conceptos evaluadores, entre afectivos y axiológicos, que emplea en relación con los personajes y objetos míticos y hasta consigo mismo: 
"Porque ese era un hombre bien compuesto, acomodado (el Aguila) ...es el que cuida a toda esa gente ese hombre, el más sabedoso y poderoso".

"...esos son Iguana, Guasuncho, Xuri, Chuña, los más ligeros".

"Era el Padre del Quirquincho, el que más sabe".

"...entonces nosotros, los viejos, hemos seguido a esos pescadores de antes" (expresión que ratifica la naturaleza cazadora de los tobas).

En cuanto al enunciatario, si bien permanece callado, su presencia en el acto de la enunciación es continuamente denunciada por el enunciador mediante apelaciones, signadas por la segunda persona gramatical en pronombres personales y morfemas flexivos verbales, $y$, también, por insistentes explicaciones o aclaraciones'sobre el hecho mítico, formuladas con total inocencia y convencimiento:

"Que me vas a creer vos que cuando bajaron esas mujeres, una entró en la tierra...".

"...parecian un tiro así, mirá vos, todas formadas en fila...".

Pero fijáte vos, esa arma que le tiran al Aguila no es un pedazo de astilla o un pedazo de leña; esa es otra arma... no es revólver, ni escopeta, ni machete; esa es otra arma...".

"¿Sabés?, que había sido que esas mujeres en la argolla tienen unos dientes... Es que habian sido tan distintas esas mujeres, boca y boca, y no comen con esa de abajo...".

"Es como ya te dije, cualquier bicho tiene su Padre".

"Ya sabés vos que el quirquincho tiene una cáscara...".

"¿Sabés que el zorro, el de él (el miembro sexual) es duro?; es duro porque es asi, un hueso que le hicieron colocar por ese que perdió".

Es indudable que enunciador y enunciatario no participan del mito enunciado de la misma manera: por un lado, el enuriciador lo vive como algo real, que se actualiza, que "se hace presente de nuevo", en opinión de Kerényi, cada vez que se lo recuerda(13), y no como "una guía errónea de conducta", según reza la conocida descalificación de Frazer (14); $y$, por otro lado, el enunciatario, ante la imposibilidad de compartirla emocional, fervorosamente, al menos le queda la satisfacción de registrar con fidelidad la mitologia toba de la que es un reconocido $y$ respetuoso investigador.

"Espacio-tiempo enunciativo//espacio-tiempo mitológico". Las nociones de espacio y tiempo no pueden tratarse por separado (sobre todo desde la intimidad de una conciencia mitica) puesto que ambas se presuponen hasta identificarse en el sentimiento de lo absoluto y eterno. Asimismo, el hombre empírico-racional se ha regodeado en separarlas, como si espacio y tiempo existieran por sí mismos en la realidad cuando, parafraseando a Francastel, no son sino creaciones de la experiencia humana(15). Para más, en el hombre 
primitivo y religioso se traban críticamente las vivencias espacio-temporales que lo llevan a distinguir entre un espacio-tiempo profano (al que pertenece el momento de la enunciación), geográfico-histórico, lineal, finito, conmensurable, y un espaciotiempo sagrado (al que pertenece el mítico), cósmico, no-lineal, infinito, inconmensurable. Pues, en la versión que analizamos, ambas cosmovisiones aparecen deslindadas en la conciencia mítica de Yorqui, aunque hoy, para poder comprender tamaña separación, nosotros debamos realizar un gran "esfuerzo de imaginación", como sostiene Priestley (16), ya que vivimos enredados en la telaraña cientificista que agobia al mundo contemporáneo. No obstante, en.el relato yorquiano, el deslinde no puede verificarse a costa de meros signos enunciativos, por cuanto sólo el espacio-tiempó real de la enunciación es el único que puede ser marcado por ciertos deícticos como los pronombres demostrativos, tanto adverbiales como adjetivos:

"...todos los animales que vemos acá, en el Chaco...".

"Por eso ahora algunas mujeres son ciegas".

"...un pedazo de víbora así, como si fuera alta asi..." (expresión que seguramente va acompañada de ademanes que señalan tamaño y altura). "...viven como nosotros arriba de esta tierra, de este mundo".

"...adentro de este monte hay Nowet";

y, también, por el presente verbal:

"...hombres, como les dicen acá; como a los que les dicen Matacos".

"Acá en el mundo hay muchos bichos; pero voy a decir, ¿que.de dónde salen esos bichos".

"Y había, ¿qué voy adecir?, había un campo lleno de agua...".

"Eran no sé cuántas las mujeres que venían en ese hilo, vamos a decir hilo pero es cadena".

"...pero también es persona... digo".

"Bueno, ¿cómo podemos decir de Juan?".

tiempo verbal presente que, para acomplejarnos más, alterna de continuo con los pretéritos narrativos:

"Al ratito bajó una mujer y pide comida... Y miraba el pobre viejo... Y claro, el Loro desconfió, y al rato se retiró; pero ya las otras alzaban cascotes para garrotearlo, y se voló; claro, tiene que disparar el pobrecito".

"Cuando el Aguila se voló, las mujeres... lo corrian con palos y cascotes. ¿Pero qué?, el hombre escapaba... cuando ve que le tiran, los ataja";

pretéritos que, si bien aluden a hechos pasados, éstos no tienen por qué ser necesariamente mitológicos. En este sentido, algo similar ocurre con los deícticos ahi, alli, antes, ese, -a,-os, -as:

"...había una bandada de pescados por alli...".

"...escarbó asii, y al ratito salió un grito de ahi".

"...esa gente pescaba; entonces nosotros, los viejos, hemos seguido a esos pescadores de antes".; 
los cuales señalan distancias, si, pero que no alcanzan a localizar el espaciotiempo originario en que se instala el mito; incluso, en la conciencia yorquiana, ambos mundos se aproximan de tal modo que resulta dificil establecer una rápida distinción entre el uno y el otro. Recuérdese, si no, que las mujeres bajan del cielo y suben a él por un simple hilo con suma facilidad y premura, o bien que, tanto deícticos como tiempos verbales que apuntan unos al pasado y otros al presente, alternan con reiterada intermitencia:

"¿De dónde viene esa gente?... ¿que de dónde salen todos esos bichos?... ¿que de adónde sale esta gente?" (refiriéndose a la misma gente).

"...en vez de decir (las mujeres del mito) que quieren quedarse acá, por si los otros las necesitan (los hombres zoomorfos)... Entonces (los hombres zoomorfos) llegaron ahi (donde estaban las mujeres del mito)".

Pero, el ejemplo más claro de que los lugares y tiempos sagrados (míticos) son sentidos como vecinos o coetáneos de la posición espacio-temporal del enunciador, lo constituye el hecho de que el demostrativo aquel no aparece en todo el relato, contrastando con la repetición apabullante de ese, -a, -os, -as que llega a convertirse en la 'muletilla' más reiterativa desde el mismísimo primer párrafo:

"Que esa gente que era de ese tiempo. Bueno, ese día se empezaban a juntar esas gentes... todos ésos eran varones... que esa era su vida, que en esa vida estaba esa gente... todos salen de ése, de ése era esa gente".

Tal fenómeno se debe, probablemente, a que la lengua toba (como otras lenguas aborigenes, incluso las hablas populares) no establece la oposición este/ese/ aquel (como el español estándard, por ejemplo), sino sólo este/ese por cuanto siempre señala 'algo' que está en su campo de acción, o bien 'algo' que, si se distancia, nunca alcanza a perderse de su vista, de su horizonte visual, ni siquiera del mitico. Es que la separación en Yorqui es más afectiva, psíquica, que real. Por eso mismo, tiene razón Marcelo Bórmida cuando nos dice: "Al leer ciertos mitos cosmogónicos tenemos la impresión de hallarnos en un mundo no muy diferente del lugar en el que vive el pueblo al que pertenecen y todo, hombres, animales y cosas, trasuntan tal 'aire de humanidad' que nos hace pensar más en una continuidad que en un verdadero tiempo originario" (17).

En definitiva, son de otro tipo las señales lingüisticas que nos acercan al espacio-tiempo mitico; pensamos sobre todo en aquellas imbricadas más por el marco referencial de la cultura toba que por el de la enunciación propiamente dicho; por ejemplo:

a) ciertas expresiones por las que se trata de explicar lo inexplicable (función primordial del mito), o bien, se mencionan seres y elementos íntimamente relacionados con la mitología toba:

"...eran de otra clase de personas (las zoomorfas)... como en forma de Nowet (dueño supremo de los animales)". 
"...esa es otra clase de armas (las que usan las mujeres uránicas); por eso requiere un hombre poderoso...como un piogonak (shaman, señor de los rituales)".

"...estaban el Padre del Guasuncho, ...del Chancho (Padres originarios de los animales)".

"...cuando bajaron esas mujeres (del cielo y por el 'hilo que es cadena'), una entró en la tierra y está escondida ahi abajo (aqui se involucran los estratos cosmogónicos: cielo, tierra, profundidades; y el axis mundi que los intercomunica)"; y sobremanera.

b) uno de los párrafos terminales del relato que marca el fin del tiempo mítico toba (el único verdadero, significativo y eterno), y, a la vez, el principio del tiempo histórico (intrascendente y efimero):

"(Después de formadas las parejas originales)... cada una de esas personas se fue al monte y sino al campo. $Y$ ahí se hace una familia $y$ salen personas, ya salen personas entonces".

Después de este somero análisis, seguimos confiando en que, mediante las estrategias del método pragmático-enunciativo, es posible aproximarnos al grado de participación afectiva experimentado por enunciador y enunciatario en relación con el mito enunciado en el momento de la enunciación, aunque con serias limitaciones. En este sentido, reconocemos que las marcas enunciativas de que nos valimos, sean deícticas o evaluativo-axiológicas, sólo nos sirvieron para delinear con cierta fidelidad la fisonomia emotiva, creyente, auténtica del informante Yorqui, pese a sus dudas y desconciertos debidoś a la compulsión políticoreligiosa extraña que sufrió la grey toba en el ámbito chaqueño y en lo que va de este siglo. En cuanto al enunciatario (el investigador-antropólogo Edgardo J. Cordeu) y al espacio-tiempo enunciativo (la población chaqueña de Miraflores, en la década del sesenta de este siglo), unas débiles marcas ostentan su perfil, pero no con mucha nitidez. Es el espacio-tiempo mítico el que se resiste a ser develado por meros signos enunciativos; apenas si se lo vislumbra como tal. Es indudable que únicamente el conocimiento cabal de la cultura toba, el cariño que sintamos por ella, pueden revelárnosla en toda su grandeza espiritual. 


\section{CONCLUSION Y SALUDO}

Las tres lecturas realizadas (simbólica, literaria y pragmático-enunciativa) constituyen, obviamente, tres interpretaciones de -o si se quiere, tres aproximaciones a- una misma variante mítica, las cuales, muy lejos de diferenciarse, se concilian de tal manera que, inclusive, parecen complementarse entre sí. Más aún: desde la alborada de los tiempos, el lenguaje creció mágico, pragmático y poético. Una entrañable necesidad de saber de dónde se viene y a dónde se va, de explicar no sólo la comṕlejidad misteriosa de esta tierra, sino también de la infinitud esotérica del cosmos; una urgente necesidad de relacionarse con los dioses fundadores y con las demás criaturas, convirtió al lenguaje en una perenne fuente de revelaciones mítico-religiosas, de leyendas y cuentos, de cánticos y oraciones, del cotidiano intercambio comunitario de experiencias y sentimientos. Más acá y más allá del logos, de la reflexión filosófica y científica, el lenguaje humano sigue cumpliendo las funciones vitales de la interacción comunicativa, cultural $\theta$ ideológica, amén de desvelar las conciencias, sobremanera la mítica que, quiérase o no, fluye inexorable por el alma humana. Conciencia mitica que dejó ya de ser retrógrada señal de primitivismo o salvajismo, de la degradante ignoracia, si no imbecilidad, de los estratos sociales marginados, para ser entendida hoy día como una forma más de conocimiento del mundo y del hombre, tan idóneo como la empírico-racional de las ciencias naturales o la socialpsicológica de las ciencias del espíritu puesto que conlleva la misma intención de hacer inteligibles todos sus fenómenos y sus actos.

Tal, la conciencia mitica de Pablo Yorqui, nuestro informante: conocedora, sin petulancias, de los misterios de este mundo, desde sus orígenes hasta su inevitable consumación; sea de la común geografía-historia terrenal, o bien del espacio-tiempo mitológico.Como el mejor de los sabios (oteólogos), Yorqui nos informa sobre (o revela) el nacimiento de la humanidad toba; y lo hace con suma convicción y firmeza, pero humildemente, sin ánimo de molestar siquiera a sus opositores religiosos o cientificos. Por lo contrario, su innata modestia lo obliga a relatarnos el mito del origen de las mujeres con fervorosa espontaneidad y, lo que más nos conmueve, en idioma español: rasgo de generosidad que nos eximió del aprendizaje de su noble lengua toba o del recurso a traductores para poder aproximarnos al sentido religioso de su autóctona cultura. Lengua toba por la que sentimos especialisimo respeto y estima, de iguali modo que Pablo Yorqui sentía por nuestro idioma español; asi como él mismo lo manifestara en las palabras dedicadas al investigador Edgardo J. Cordeu ("Aproximación al horizonte mítico de los tobas", obra citada de la que extrajimos el relato de Yorqui, p. 172), y que aqui dejamos estampadas como íntimo saludo para todos los hermanos aborigenes y de la raza ibeoamericana:

"A mi hermano que ha venido por tantas leguas, que me gusta que venga a saludar. $Y$ yo también lo saludo en nuestra mirada".

"Que estoy hablando hoy con esas palabras con que nunca he hablado. Gracias a Dios que aún tengo su memoria. Que esa palabra no se pierda nunca, que hasta el fin dure. Hasta el fin que no muera mi palabra". 
"Gracias a Dios que aún puedo hablar por la palabra de España. $Y$ por mi, los de más adelante, los que se fueron ya".

"Que venga a buscar mi hermano por mi todas las palabras que necesite. Que venga a llevar, que lleve. Tampoco mi palabra le mezquino, la palabra que necesita llevar. Que lleve, que no le mezquino mi palabra".

"Es luz, es flor mi palabra".

Pablo Yorqui 


\section{NOTAS}

\section{Capitulo I}

1.- M. Eliade, Mefistófeles y el andrógino, Guadarrama, Madrid,1969; en esta obra, cap. 4 y 5; del mismo autor, Imágenes y Símbolos, Tratado e Historia de las Religiones. Vicente Fatone, El hombre y Dios, Esquemas, Buenos Aires, 1963.

2.- R.Lehmann Nitsche, La Astronomía de los tobas, en Revista del Museo de La Plata, Tomo XXVIII, 1ra. Parte, 1923; R. Karsten, Indian tribes of the Argentine and Bolivian Chaco, Helgsinfors, Finland, 1932; A. Métraux, Myths of the Toba and Pilagá indians of the Gran Chaco, Philadelphia, American Folklore Society, 1946; E. Palavecino, Mitos de los indios toba en RUNA, Tomo XII, Bs. As. 1970; E. Cordeu, Aproximación al horizonte mítico de los tobas, en RUNA, Tomo XII, Bs. As. 1970; Sara Newbery y Buenaventura Terán, sus mitos traducidos al inglés en J. Wilbert and. $K$. Simoneau, Folk Literature of theToba indians, edit. UCLA, Latin American Center Publications, University of California, Los Angeles, 1982, este volumen incluye, vertidos al inglés, los mitos tobas recopilados por los autores antes mencionados. Orlando Sánchez, Antiguos relatos tobas, Toqueshic l' aqtaxanaxac na Qompi, edit. Junta Unida de Misiones, Bs. As. 1987, Sánchez es pastor toba, residente en Colonia Juan José Castelli, provincia del Chaco, publica los relatos oidos en Miraflores, Chaco, y en Colonia El Alba, Formosa, datos que revela en su libro Los Tobas, cultura, tradiciones, leyendas, ed. Búsqueda, 1986, también consultado para esta comunicación, Susana Colazo, antropóloga de la UNNE recogió, en 1990, una versión de este mito, en el interior del Chaco.

3.- M. Eliade, los dos primeros libros citados en nota 1.

4. Dice Pablo Yorqui, informante de Cordeu en 1969: "Yo creo que el Dios manda esas mujeres, para que los otros las agarren y se queden también con ellas. Pero ellas no se presentaron como si vinieran a querer quedarse, sino que vienen a robar, en vez de decir que quieren quedarse acá, por si los otros las necesitan".

5.- Yorqui hablando del Quirquincho: "...él también era el Pàdre del Quirquincho, él, el que más sabe". En Karsten y Métraux está documentado que cuando las niñas púberes, después de su primer periodo, pasan a integrar el grupo de mujeres, comen carne de armadillo, para ser fecundas. El armadillo es el único animal que pueden cazar las mujeres.

6.- José Cardús, Las misiones franciscanas entre los infieles de Bolivia, Barcelona, 1886. 


\section{Capitulo II}

1.- Walter J. Ong, Oralidad y escritura. Tecnologia de la palabra, México, FCE, 1'a. edición española, 1987.

2. Ibídem.

3. Susana Chertudi, El cuento folklórico, Centro Editor de América Latina, Buenos Aires, 1967.

4.- Ibidem.

5.- Walter J. Ong, op. cit.

6.- Ibidem.

\section{Capitulo III}

1.- Adoptamos la versión recogida por Edgardo J. Cordeu en su trabajo "Aproximación al horizonte mítico de los tobas", publicado en RUNA, revista del Instituto de Ciencias Antropológicas (UBA), Vol. XII, Partes 12, Buenos Aires, 1969-1970, pp. 143-146.

2.- Vid. José Ortega y Gasset, "Prólogo para franceses". en La rebelión de las masas, Madrid, Revista de Occidente, 1961, pp. 5-6.

3.- Cfr. M. Eliade, Lo sagrado y lo profano, Barcelona, Labor, 1967, p. 5.

4.- Vid. Bronislav Malinowski, "El problema del significado en las lenguas primitivas", en C. K. Ogden \& I. A. Richards, El significado del significado. Una investigación acerca de la influencia del lenguaje sobre el pensamiento y de la ciencia simbólica, Barcelona, Paidós, 1984 p. 320. (Los corchetes nos pertenecen).

5.- Vid. M. Bormida, "Problemas de heurísticas mitográfica. Las fuentes miticas a nivel etnográfico", en RUNA, ya cit., p. 62.

6.- Cfr. Catherine Kerbrat-Orecchioni, La enunciación. De la subjetividad en el lenguaje, Buenos Aires, Hachette, 1986, p. 43. Es claro que aquí la autora aclara en qué consiste la problemática de la teoría de la enunciación.

7.- Vid. Nota (1) en este mismo trabajo. El estudio de Cordeu aparece completo entre las páginas 67 y 176.

8.- Cfr. E. J. Cordeu, op. cit., p. 67.

9.- Cfr. Elmer S. Miller, Los tobas argentinos. Armonía y disonancia en una sociedad, México, Siglo Veintiuno, 1979, Nota 14, p. 52.

10.- En realidad, E. S. Miller dedica gran parte de la obra citada a esclarecer este proceso de cambio sufrido por los tobas del Chaco en este último siglo, sobre todo en lo que respecta al influjo evangélico pentecostal.

11.- Vid. Mijail Bajtin, "Autor y personaje en la actividad estética", en Estética de la creación verbal, México, Siglo XXI, 1985, pp. 28-29.

12.- Cfr. Ernst Cassirer, Filosofía de las formas simbólicas, II (El pensamiento mítico), México, Fondo de Cultura Económica, 1979, p. 189.

13.- Cfr. Karl Kerényi. La religión antigua, Madrid, Revista de Occidente, 1972, 
pp. 31 y ss. En este lugar, el autor entiende que la mitología incluso, presume una forma de pensar.

14.- Cfr. JamesG. Frazer, La rama dorada. Magia y religión, México, Fondo de Cultura Económica,1980, pp. 34 y 35. Aquí dice concretamente: "...la magia es un sistema espurio de leyes naturales asi como una guia errónea de conducta; es una ciencia falsa y un arte abortado... no tan sólo para la inteligencia ruda del salvaje, sino tamién para la de la gente ignorante y estupida de todas partes".

15.- Cfr. Pierre Francastel, Pintura y sociedad. Nacimiento y destrucción de un espacio plástico. Del renacimiento al cubismo, Buenos Aires, Emecé, 1960, p. 42. En este lugar sostiene refiriéndose al espacio: "El espacio no es una realidad en sí, cuya representación varíe seqún las épocas. El espacio es la experiencia misma del hombre".

16.- Cfr. J.B. Priestley, El"hombre y el tiempo, Madrid, Aguilar, 1969, p. 138. Aquí mismo reflexiona en torno de nuestra idea del tiempo: "Resulta particularmente necesario un esfuerzo de imaginación... Nuestras mentes están aferradas a la noción del irresistible tiempo que pasa...que tendremos que arrancar a nuestras mentes de esa noción, para comprender lo que pensaban y sentian otars gentes. Este esfuerzo, es particularmente necesario cuando consideramos al hombre primitivo".

17.- Vid. M. Bórmida, "Mito y cultura. Bases para una ciencia de la conciencia mitica y una etnología tautegórica". en RUNA, ya cit., p. 30. 


\section{BIBLIOGRAFIA}

\section{Capítulo J}

Eliade, M., "Imágenes y símbolos", "Tratado de Historia de las Religiones", "Mefistófeles y el Andrógino", "Lo sagrado y lo profano", "El Chamanismo".

Eliade, M., Kitagawa, "Metodología de Historia de las Religiones".

Fatone, V., "El hombre y Dios", Esquemas, Buenos Aires, 1963.

Brandon, S.G.E., "Diccionario de Religiones Comparadas", Cristiandad, Madrid, 2 tomos.

Massuh, V., "El rito y lo sagrado", Columba, Buenos Aires, 1965.

Guénon, R., "Simbolos fundamentales en la ciencia sagrada", Eudeba, 1969.

Cirlot, J.E., "Diccionario de símbolos", Barcelona, Labor, 1969.

Pérez Rioja, "Diccionario de símbolos y mitos", Tecnos, Madrid, 1971.

Niklison, J.E., "Los tobas", Universidad Nacional de Jujuy, 1990.

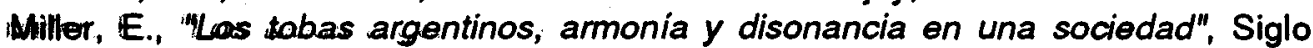
XXI editores, Mëxico, 1979.

Sánchez, O., "Los tobas, cultura, tradiciones, leyendas", ed. Búsqueda, Bs. As. 1986.

Susnik, B., "Los aborigenes del Paraguay", tomo VI, Aproximación a las creencias de los indigenas, Museo Etnográfico "Andrés Barbero", Asunción, Paraguay, 1984-1985.

Lehmann- Nitsche, R., "La astronomía de los tobas", Revista del Museo de La Plata, t. XXVII y XXVIII, 1923-25.

Karsten, R., "Indian tribes of the Argentine and Bolivian Chaco", Helsingfors, Finland, 1932.

Métraux, A., "Myths oft he Toba and Pilagá indians of the Gran Chaco", Philadelphia, American Folklore Society, 1946.

Cordeu, E., "Aproximación al horizonte mítico de los tobas", en RUNA, t. XII, Buenos Aires, 1970.

Palavecino, E., "Mitos de los indios tobas" en RUNA, t. XII, Bs. As., 1970.

Wilbert, J., and Simoneau, K., "Folk Literature of the toba indians", UCLA, Latin American Center Publications, University of Califomia, Los Angeles, 1982.

Sánchez, O., Antiguos relatos tobas, Togheshic I' aqtaxanaxac na Qompi, Junta Unida de Misiones, Bs. As., 1987.

Cardús, José, "Las misiones franciscanas entre los infieles de Bolivia", Barcelona, 1886, citado por Karsten.

\section{Capítulo III}

John L. Austin, "Cómo hacer cosas con palabras. Palabras y acciones", Barcelona, Buenos Aires, Paidós, 1982.

Mijail M. Bajtin, "Estética de la creación verbal", México, Siglo XXI, 1985. Proble- 
mas de la poética de Dostoievski, México, Fondo de Cultura Económica, 1986.

Emile Benveniste; "Problemas de lingüistica general", I y II, México, Siglo XXI, 1971 y 1978.

Marcelo Bórmida, "Mito y cultura. Bases para una ciencia de la conciencia mítica y una etnología tautegórica", en RUNA, Buenos Aires, Instituto de Ciencias Antropológicas (UBA), 1969-1970, Vol. XII, Partes 1-2.

"Problemas de heuristica mitográfica. Las fuentes míticas a nivel etnográfico", en RUNA, op. cit..

Ernst Cassirer, "Filosofía de las ciencias simbólicas", 3 vols., México, Fondo de Cultura Económica, 1979.

Edgardo J. Cordeu, "Aproximación al horizonte mítico de los tobas", en RUNA, op cit..

Oswald Ducrot, "El decir y lo dicho", Buenos Aires, Hachette, 1976.

Mircea Eliade, "Lo sagrado y lo profano", Barcelona, Labor, 1967. "El mito del eterno retorno. Arquetipos y repetición", Buenos Aires, 1960.

Pierre Francastel, "Pintura y sociedad. Nacimiento y destrucción de un espacio plástico", Buenos Aires, Emecé, 1960.

James G. Frazer, "La rama dorada. Magia y religión", México, Föndo de Cultura Económica, 1980.

Román Jakobson, " "Ensayos de lingüística general". Barcelona, Ariel, 1984.

Catherine Kerbrat-Orecchioni, "La enunciación.De la subjetividad en el lenguaje". Buenos Aires, Hachette, 1986.

"La connotación". Buenos Aires, Hachette, 1983.

Karl Kerényi, "La religión antigua". Madrid, Revista de Occidente, 1972.

Claude Lévi-Strauss, "Antropología estructural", Buenos Aires, EUDEBA, 1984.

Bronislav Malinowski, "El problema del significado en las lenguas primitivas", en C. K. Ogden \& I.A. Richards, "El significado del significado. Una investigación de la influencia del lenguajo sobre el pensamiento y de la ciencia simbólica", Barcelona, Paidós. 1984.

Wilbur Marshall Urban, "Lenguaje y realidad. La filosofía del lenguaje y los principios del simbolismo", México, Fondo de Cultura Econémica, 1952.

Elmer S. Miller, "Los tobas argentinos. Armonía y disonancia en una sociedad", México, Siglo XXI, 1979.

J. B. Priestley, "El hombre y el tiempo", Madrid, Aguilar, 1969.

Francois Récanati. "La transparencia y la enunciación. Introducción a la pragmática", Buenos Aires, Hachette, 1981.

John Searle, "Actos de habla. Ensayo de filosofía del lenguaje", Madrid, Cátedra, 1986.

Teun A. Van Dijk, "Estructuras y funciones del discurso", México, Siglo XXI, 1980. "La ciencia del texto. Un enfoque interdisciplinario", Buenos Aires - Barcelona, Paidós, 1978.

"Texto y contexto. Semántica y pragmática del discurso", Madrid, Cátedra, 1984. 